\title{
ARTIGOS
}

\section{A MORTE DE PERICLE DUCATI E A ETRUSĊOLOGIA.}

Com o desaparecimento do Prof. Pericle Ducati, a etruscologia perdeu um dos seus mais ilustres cultores.

Pericle Ducati nasceu em Bolonha, no dia 11 de julho de 1880. Obteve a láurea na Universidade de Bolonha, onde foi discipulo do Prof. Eduardo Brizio, em 1902. No princípio da sua carreira, foi Inspetor do Museu Cívico e Superintendente das Escavações e dos Museus em Bolonha e livre docente de Arqueologia na Universidade da mesma cidade. Em 1912 foi nomeado titular de Arqueologia da Universidade de Catânia e em 1916 na Universidade de Turim. Em 1923 foi Presidente da Faculdade de Filosofia e Letras da Universidade de Bolonha.

Tornou-se membro de várias Academias; membro correspondente da Academia dos Linces, dos Institutos Arqueológicos Germânico e Austríaco e honorário da Academia de Ciências de Bolonha.

No 1.0 "Convegno Nazionale Etrusco", realizado em Florença, em 1925, Pericle Ducati foi um dos mais profundos e originais ilustradores, a respeito das novas descobertas sôbre a arte etrusca. $O$ seu nome tornou-se universal devido à sua atividade científica, especialmente no campo da cerâmica grega e no das antiguidades italo-etruscas.

Além de muitos artigos e estudos de valor, em revistas de Arqueologia e em outros orgãos, publicou vários trabalhos nos alentados e belos volumes da série "Studi Etruschi", orgão e arquivo precioso do "Istituto di Studi Etruschi". Convém mencionar a sua conferência: Problami di Arte e di Civiltá Etrusca (1. ${ }^{\circ}$ Convegno Nazionale Etrusco: Atti, vol. II, 1926, Firenze). Publicou dois trabalhos sôbre a cerâmica da Grécia: Maedia ed e vasi midiaci e La Ceramica Attica do século IV a. C. (Memorie della R. Accademia dei Lincei, 1909 e 1916). O trabalho Arte e Antichità Etruschi. Le Pietre Funeraria felsinee (Monumenti della R. Accademia dei Lincei, 1911), é outra publicação. Escreveu a Arte Clas- 
sica, 1920 e a volumosa obra Storia della Ceramica Greca, 1923; o Manual L'Arte di Grecia e di Roma; a apreciadíssima obra Etrutia Antica, 1925, que foi um sucesso literário; Gli Etruschi, 1928; e a volumosa obra Storia dell'Arte Etrusca, que representa a última palavra da ciência arqueológica, referente à expressão artística dos etruscos.

Vários são os problemas que aparecem relativamente ao estudo dos etruscos. Devem ser apontados entre êles, por serem de grande importância: a sua origem e a sua língua.

Apresentamos algumas teorias modernas a respeito da origem dos etruscos, conforme Pericle Ducati, em seu trabalho Gli Etruschi:

$1 .^{\circ}$ Os etruscos são o produto da fusão de povos itálicos, isto é, umbros e proto-etruscos colonizadores, que vindos do oriente asiático tulavam uma lingua afim com a língua da Ásia Menor. A colonização processou-se mais ou menos pelo fim do século VIII a. C.;

2. Os etruscos pertencem ao grupo indo-europeu e não são diferentes das outras populações itálicas (latinos, umbros, etc.), com os quais tiveram civilização comum e afinidades lingüísticas. Desceram êles com os outros itálicos dos Alpes para a península italiana, dando assim origem aos etruscos do norte do vale do Pó e à Etruria pròpriamente dita, do sul dos Apeninos. Isso efetuou-se pelos séculos XII - XI a. C.;

3. ${ }^{0}$ Os etruscos são considerados descendentes diretos dos terramares ou "abitatori di palafitte in terreno paludoso dell'età del bronzo nella pianura padana, e i terramaricolli sarebbero pervenuti in questa pianura attraverso i valichi alpini";

4. ${ }^{\circ}$ Constituem os etruscos um extrato étnico, anterior ao representado pelas populações itálicas, observando-se que a língua etrusca agrupa-se com as línguas da Ásia Menor, faladas por povos pertencentes à mesma estratificação;

5. Baseando-se nos autores clássicos, afirma-se a proveniência dos etruscos da Espanha, sendo portanto considerados iberos. etrusca.

Não menos variadas são as hipóteses concernentes à língua

Prende-se a língua etrusca às línguas indígenas da América; ao hebraico, ao caldaico, aramaico, portanto é considerada língua semítica; afirma-se ser ela itálica, idioma misto; liga-se ao grego, ao armêtio; assegura-se que é idioma ário, fenício, magiaro, tráciofrígio-ibérico, albanês, lício, cário, lídio, georgiano, pré-armênio, elamita ou sussiano, cássio, hitita, turco, egípcio, sânscrito, céltico germânico, balto-eslavo, basco, dravídico, etc. O iđioma etrusco é pois considerado afim a quase tôdas as línguas do mundo.

O etrusco não é um idioma isolado. Para determinar seu próximo parentesco de uma língua, é mister procurar saber com que 
grupo lingüístico ela apresenta o máximo das concordância e se apresenta concordâncias especiais, não encontradas em outros grupos lingüísticos.

Parece que os estudos mais apurados, na questão da afinidade lingüística, são do Prof. Trombetti. O etrusco, diz êle, pertence a um grupo de línguas extintas, sendo intermédió entre o caucásico e indo-europeu, porém mais próximo a êste. A tal grupo pertencem também as pré-helênicas da Grécia e do Egeu (Lemenos, Creta, etc.), a maior parte dos idiomas antigos da Ásia Menor (isto é, as línguas da Lícia, Lídia, Cária, etc.), compreendido o hitita. Com estas línguas o etrusco tem parentesco de primeiro grau, de segundo grau com as línguas indo-européias e de terceiro grau com as línguas caucásicas (georgiano, etc.).

Sob os aspecto histórico e geográfico, đistingue-se na Ásia Anterior e na Europa Meridional ou então da zona que vai do Cáucaso aos Pireneus, três grandes estratificações lingüísticas:

1. ${ }^{\circ}$ Basco-caucásico ou ibero-caucásico. Esta é a camada mais antiga que perdura nas duas regióes extremas, enquanto que no restante permanecem sòmente traços;

2. Etrusca-asiânico e Pré-indo-europeu. As línguas dêste grupo sobrepuseram-se às precedentes, ocasionando a sua extinção na larga zona mediana em que elas podiam se espalhar (Itália, Península balcânica e Egeu, Ásia Menor);

$3 .^{\circ}$ ) Indo-europeu. Esta é a camada mais recente, de proveniência setentrional, que se sobrepôs às suas precedentes, ocasionando a extinção total do segundo.

Finalmente, na interpretação das inscrições etruscas, dois métodos teem sido empregados: o etimológico, que consiste em interpretar o etrusco confrontando-o com as outras línguas consideradas pròximamente afins e o método combinatório, que consiste em interpretar o etrusco por meio do etrusco, sem se fundar portanto em possíveis ou reais afinidades com outras línguas conhecidas.

Embora ainda perdurem os problemas referentes ao povo etrusco e à sua língua, forçoso é confessar que alguma luz se tem projetado nesses estudos. Para isso muito contribuiu Pericle Ducati como historiador e especialmente como arqueólogo.

Não é sem razão portanto que a morte de Ducati seja profundamente sentida na esfera científica, referente á etruscologia. 